\title{
Effect of Green Manure Application on Soil Enzyme Activity and Nutrient Dynamics in a Sugarcane Field of Kitadaito, Okinawa, Japan
}

\author{
Susan MAMBU ${ }^{1}$, Soh SUGIHARA ${ }^{1 *}$, Takumi KAWAME ${ }^{1}$, \\ Tomohiro NISHIGAKI ${ }^{1}$, Koki TOYOTA ${ }^{1}$, Naoko MIYAMARU ${ }^{2}$, \\ Haruo TANAKA ${ }^{1}$ and Motoki KANEKATSU ${ }^{1}$ \\ ${ }^{1}$ United Graduate School of Agricultural Science, Tokyo University of Agriculture and Technology \\ (Fuchu, Tokyo 183-8509, Japan) \\ ${ }^{2}$ Okinawa Prefectural Agricultural Research Center (Itoman, Okinawa 901-0336, Japan)
}

\begin{abstract}
To achieve sustainable sugarcane cultivation in subtropical cropland of Okinawa, Japan, it is necessary to improve and maintain the soil fertility by organic matter application. In most islands of Okinawa, green manure (GM) application is commonly used to improve the soil organic matter content because of its cost effectiveness. In this study, we evaluated the effect of application of different GMs, i.e., Crotalaria juncea (CRO) and Sesbania cannabina (SES), on soil nutrient dynamics in relation to soil enzymes, which are a sensitive indicator of land management in a sugarcane field of Kitadaito, Okinawa. We evaluated the fluctuation of soil enzymes (dehydrogenase [DH], $\beta$-glucosidase [BG], and phosphomonoesterase [PHO]), soil nutrients (extractable carbon [Ext-C] and nitrogen [Ext-N], and available phosphorus [Avail-P]) with environmental conditions after GM application for seven months. We also measured the sugarcane growth parameters seven months after planting. Application of CRO and SES clearly increased the BG and PHO activities throughout the experimental period and increased the sugarcane number (ca. 11\%-20\%), but they did not increase the DH activity and soil nutrients (e.g., Ext-C and Avail-P). Application of CRO also increased Ext-N, but SES application had no clear effect, possibly because of the different GM quality and decomposition patterns. Thus, our results showed that CRO is the preferred GM species in terms of improvement of soil enzyme and nutrient conditions for GM-sugarcane cropping systems in Kitadaito.
\end{abstract}

Discipline: Soils, fertilizers and plant nutrition

Additional key words: $\beta$-glucosidase, Crotalaria, dehydrogenase, phosphomonoesterase, Sesbania

\section{Introduction}

Sugarcane is one of the major cash crops in the humid tropics. In Okinawa prefecture, southern Japan, sugarcane is one of the basic agricultural products and is a major crop that supports the economy of most islands of Okinawa. It thus plays a key role in the regional economy. However, recent studies have reported that sugarcane production has gradually decreased, mainly owing to the continuous cropping, inefficient fertilization (Kikuchi et al. 2007) and unfavorable weather conditions, e.g., typhoons, and drought (Matsuoka 2006). Soil organic matter (SOM) content is generally inherently low and difficult to increase, largely because of the high temperature and humidity under the subtropical climate conditions, and continuous cropping has been shown to decrease the soil organic carbon (C) and available nitrogen $(\mathrm{N})$ in Okinawa (Miyamaru et al. 2011, Yoshida et al. 2016). To achieve sustainable sugarcane production in Okinawa, it is necessary to improve and maintain the SOM of sugarcane cropland. Cooperation of agriculture and livestock has been trialed on the islands to add organic matter (OM) into the sugarcane cropland to promoter cycling of organic resources, but this approach remains unpopular and is difficult in the smaller islands of Okinawa, mainly due to the limited cropland area and human resources.

In general, the application of legume green manure (GM) is considered a practical and functional approach to recover soil fertility, because it improves the soil physical

*Corresponding author: e-mail: sohs@cc.tuat.ac.jp

Received 20 December 2017; accepted 19 February 2018. 
conditions, supplies nutrients for subsequent plant growth, and stimulates the soil microbial dynamics, such as enzyme activity (Goyal et al. 1999, Cherr et al. 2006, Kumar et al. 2013). Many studies have observed that the incorporation of GM increases the soil organic C, available $\mathrm{N}$, phosphorus (P), potassium, and sulfur contents even in tropical croplands (Sangakkara et al. 2004, Bokhtiar \& Sakurai 2005, Mabuza et al. 2016). However, in Okinawa, GM cultivation is not currently popular, except for in Miyakojima Island, because most local farmers want to conduct ratooning sugarcane cultivation, which is a labor-saving and cost-effective cultivation method. At present, GM cultivation in Okinawa is generally conducted after 3-4 years of continuous sugarcane cultivation, if it is conducted at all. To prevent the further depletion of SOM in Okinawa, GM cultivation should be popularized; however, there is little information on the effect of GM cultivation and/or application on soil nutrient dynamics in Okinawa. This is because a low rate of GM application is used (3-5 Mg C $\mathrm{ha}^{-1}$ ) and there has only been a single application every 3-4 years. It is therefore difficult to detect the clear increase of soil organic $\mathrm{C}$ and $\mathrm{N}$, while some positive effect, such as better crop yields, should occur through GM application (Burgos et al. 2002, Sangtong \& Katoh 2010, Carvalho et al. 2015).

Soil enzymes are generally used as an indicator of various land management, because of their sensitivity and ease of measurement (Kirchner et al. 1993, Bandick \& Dick 1999). Soil enzymes are mainly released by soil microbes, and play an important role in OM decomposition processes. Surucu et al. (2014) showed that the application of leguminous GM increased the soil enzyme activity depending on amount of application and chemical composition of the GM. They found that the application of faba bean increased the soil urease and dehydrogenase activities, compared with conventional fertilization. Miyamaru (2013) also observed that OM application increased the soil microbial biomass $\mathrm{C}$ and $\mathrm{N}$ in an Okinawa sugarcane field, although they did not evaluate the soil enzyme activity. These results suggest that the analysis of soil enzyme activity is a good indicator of the effect of GM application on soil nutrient dynamics in a GM-sugarcane cropping system in Okinawa. In the current study, we mainly focused on dehydrogenase (DH), $\beta$-glucosidase (BG), and phosphomonoesterase (PHO) activities, which are strongly related to nutrient dynamics of soil (Tabatai 1982, Bandick \& Dick 1999). $\mathrm{DH}$ is considered to be an indicator of soil microbial decomposition activity (Salazar et al. 2011), BG is considered to be an indicator of $\mathrm{C}$ mineralization (Stott et al. 2010), and PHO is considered to be an indicator of $\mathrm{P}$ mineralization (Debnath et al. 2015). We hypothesized that the application of GM stimulates the $\mathrm{DH}, \mathrm{BG}$, and $\mathrm{PHO}$ activities, resulting in the increase of available soil $\mathrm{N}$ and/or $\mathrm{P}$ in sugarcane croplands of Kitadaito, Okinawa. Owing to many studies showing the relationship between soil enzymes and environmental conditions, such as soil temperature and moisture (Sinsabaugh 1994, Feng et al. 2009), it is also necessary to assess seasonal fluctuations and reveal the factors controlling soil enzyme activity under field conditions.

Therefore, our objectives were: (1) to evaluate the effects of GM application on soil enzyme activities and soil nutrient dynamics; and (2) to investigate the relationship between soil enzyme activities and soil nutrient dynamics associated with environmental factors in a sugarcane field of Kitadaito, Okinawa. We also evaluated the early sugarcane growth parameters (seven months after planting) to assess the effect of GM application on sugarcane growth.

\section{Materials and methods}

\section{Description of the study sites}

The field experiment was conducted from May 2016 to April 2017 in a sugarcane field $\left(25^{\circ} 57^{\prime} 05.9^{\prime \prime} \mathrm{N}, 131^{\circ} 19^{\prime} 26.1^{\prime \prime} \mathrm{E}\right)$ of a local farmer's cropland on Kitadaito Island, which is located $360 \mathrm{~km}$ east of the main island of Okinawa. The site is located in a subtropical climate, and annual rainfall during the experimental period was $1,170 \mathrm{~mm}$ with average air temperature $24.5^{\circ} \mathrm{C}$. The soil in our experimental field was classified as Inceptisols (Soil Survey Staff 2014) and was locally called "Daito-mahji” (Onaga \& Yoshinaga 1988, Tokashiki 1993, Miyamaru 2013).

The soil color is mostly reddish brown to yellowish brown and is characterized by heavy clay texture. In brief, soil characteristics of the plow layer $(0-15 \mathrm{~cm})$ before the experiment, i.e., April 2016, were as follows: soil $\mathrm{pH}\left(\mathrm{H}_{2} \mathrm{O}\right)$ was 5.1 ; and $89 \%$ clay; $10 \%$ silt; and $1 \%$ sand. Total organic $\mathrm{C}$ and $\mathrm{N}$ was $19.8 \mathrm{~g} \mathrm{C} \mathrm{kg}^{-1}$, and $2.1 \mathrm{~g}$ $\mathrm{N} \mathrm{kg}^{-1}$, respectively, cation exchange capacity was 22.1 $\mathrm{cmol}_{\mathrm{c}} \mathrm{kg}^{-1}$; and the $\mathrm{P}$ adsorption capacity was $816.2 \mathrm{mg}$ $\mathrm{P}_{2} \mathrm{O}_{5} 100 \mathrm{~g}^{-1}$, which is relatively high because of the high level of crystalline iron (Fe) present in the soil. Soil pH was measured by the glass electrode method (soil:water ratio 1:2.5). Soil particle size distribution was determined by wet-sieving and pipette method (Gee \& Or 2002). Total organic $\mathrm{C}$ and $\mathrm{N}$ were quantified by dry combustion methods with a NC analyzer (SUMIGRAPH NC-TR22, Sumika Chemical Analysis Service, Ltd.). Cation exchange capacity was determined by the Ammonium Acetate method at pH 7.0-Lavkulich 1981 (Hendershot et al. 2008), and $\mathrm{P}$ adsorption capacity was determined 
according to the method by Sekiya (1970).

\section{Field experimental design}

The experimental plots $(6 \mathrm{~m} \times 4.5 \mathrm{~m})$ were arranged in a complete randomized block design using three replicate plots per treatment with a 1-1.5 m buffer area. We cultivated two different GM varieties: Crotalaria juncea (CRO) and Sesbania cannabina (SES), according to the recommended seed density by Okinawa prefecture (50 kg seed ha ${ }^{-1}$ in CRO and $30 \mathrm{~kg}$ seed ha- in SES). These GM varieties are most popular GM for sugarcane crop land in Okinawa. We planted GM from $6^{\text {th }}$ May to $28^{\text {th }}$ July 2016, which was incorporated into the surface soil (ca. 0-15 cm soil depth) in each plot by machine plowing at the end of July 2016. Before the incorporation of each GM, we chopped the plant materials into 10-15 $\mathrm{cm}$ pieces by using a glass cutter. The plant biomass $\mathrm{C}$ was 3.4 and $5.1 \mathrm{Mg} \mathrm{C}^{-1}$ in CRO and SES, respectively, and plant biomass $\mathrm{N}$ was 130 and $170 \mathrm{~kg} \mathrm{~N} \mathrm{ha}^{-1}$ in CRO and SES, respectively. The C:N ratio of applied plant biomass was 26 and 30 in CRO and SES, respectively, which was low because of the leguminous $\mathrm{N}$ fixation capacity. The C:N ratio of leaf was 10 and 11 in CRO and SES, respectively, while the C:N ratio of stem was 65 and 55 in CRO and SES, respectively. These amounts of C and $\mathrm{N}$ by CRO and SES were within the average in this district.

In addition to CRO and SES plots, we also established the bare plot during this GM cultivation period as a control plot (Cont). After plowing in the CRO, SES and Cont plots, we planted the sugarcane at all three plots on $1^{\text {st }}$ September 2016, which was ca. four weeks after GM incorporation. After the planting of sugarcane, machine plowing in the furrow was conducted twice $\left(22^{\text {nd }}\right.$ November 2016 and $6^{\text {th }}$ January 2017) for all plots to remove weeds. Chemical fertilizer was also applied to all plots, according to the recommendation of Okinawa prefecture, as follows: $97 \mathrm{~kg} \mathrm{~N} \mathrm{ha}^{-1}$; $36 \mathrm{~kg} \mathrm{P} \mathrm{ha}^{-1}$; and 36 $\mathrm{kg} \mathrm{K} \mathrm{ha}{ }^{-1}$ The chemical fertilizer was applied on the center of the ridge where the sugarcane seeds were planted, and this fertilization was conducted three times ( $1^{\text {st }}$ September 2016, $22^{\text {nd }}$ November 2016, and $6^{\text {th }}$ January 2017) at the same time as machine planting or plowing. The experiment was mainly maintained under rain-fed cultivation, but we conducted drip irrigation if the soil was too dry to grow the sugarcane. The amount of irrigation water applied was relatively small because the water resource is quite limited in isolated Kitadaito Island.

\section{Soil environmental monitoring}

The air temperature (AT) and soil temperature (ST) at a depth of $5 \mathrm{~cm}$ and the volumetric soil moisture content (SM) at 0-15 cm were monitored every half hour in the CRO and Cont plots in duplicate, using a data logger system (107 thermistor probes for temperature and CS616 for volumetric SM were connected to a CR-10X data logger; Campbell Scientific Inc., USA). As a result of the limited number of available probes, we could not install the probes in the SES plot, and thus we assumed that fluctuation of ST and SM in the SES plot was similar to the values that were recorded in the CRO plot. During the sugarcane cultivation period, we installed the ST and SM probes within 20-30 $\mathrm{cm}$ of sugarcane ridge (similar point of soil samples), and when the machine plowing was conducted, we removed the whole probes temporally and reinstalled them later in the same point. Rainfall was also monitored every half hour at the experimental site, using the same CR10X data logger system and a TE525MM rain gage (Campbell Scientific Inc.).

\section{Soil sampling and analysis}

Soil samples were collected 14 times from the surface soil layer $(0-15 \mathrm{~cm})$ through a one-year experimental period (five times in GM cultivation and nine times in sugarcane cultivation). For each sample, five soil samples were taken within the plot, and were combined and mixed for each replication. During the sugarcane cultivation period (i.e., from September 2016 to April 2017), we collected the soil samples within 20-30 $\mathrm{cm}$ of the sugarcane ridge, although not from the center of the ridge, to eliminate the effect of drip irrigation or fertilization on measured soil enzymes and/or nutrients. The soil was passed through a 4-mm sieve and subsequently stored at low temperature $\left(4^{\circ} \mathrm{C}\right)$ as a fresh soil for analyzing the biological properties (the soil enzyme activities and soil nutrients). All these measurements were conducted within three months of sampling. Dehydrogenase (DH) activity was evaluated by both the iodonitrotetrazolium chloride (INT) method of Hayano (1997) and the methanol and colorimetric determination method (Tabatai 1994). Briefly, $1 \mathrm{~g}$ soil was mixed with $1 \mathrm{ml} 0.25 \mathrm{M}$ Tris buffer ( $\mathrm{pH} 7.6), 1 \%$ glucose, and $2 \mathrm{ml}$ of $0.4 \%$ INT solution. The sample was incubated at $30^{\circ} \mathrm{C}$ for $6 \mathrm{~h}$, mixed with $10 \mathrm{ml}$ of methanol and analyzed colorimetrically at $485 \mathrm{~nm}$. Determination of $\beta$-glucosidase (BG) was conducted according to Hayano $(1973,1997)$, with modifications. These methods involved incubating the $0.3 \mathrm{~g}$ soil with $0.1 \mathrm{ml}$ of toluene, $0.9 \mathrm{ml}$ of distilled water, $1.5 \mathrm{ml}$ of citric acid phosphate buffer ( $\mathrm{pH} 4.9$ ) and $1.5 \mathrm{ml}$ of $50 \mathrm{mMp}$-nitrophenyl $\beta$-Dglucoside. After incubation at $30{ }^{\circ} \mathrm{C}$ for $1 \mathrm{~h}, 8 \mathrm{ml}$ of ethanol was added and then the solution was filtered and mixed with 2M Tris solution and analyzed colorimetrically 
at $400 \mathrm{~nm}$. Phosphomonoesterase activity (PHO) was also determined based on colorimetric determination using sodium $p$-triphenyl phosphate (PNP) (Hayano, 1997), with modifications. Briefly, 0.3 g soil was mixed with $0.1 \mathrm{ml}$ of toluene, $6.5 \mathrm{ml} 0.5 \mathrm{M}$ Tris-malate buffer (pH 6.5), $1.8 \mathrm{ml}$ distilled water, and $0.6 \mathrm{ml} 50 \mathrm{mM}$ of PNP. After incubation at $30{ }^{\circ} \mathrm{C}$ for $1 \mathrm{~h}, 8 \mathrm{ml}$ of ethanol was added, then the solution was filtered and $2 \mathrm{M}$ Tris solution was added. The produced color intensity was measured colorimetrically at $400 \mathrm{~nm}$. All measurements were conducted in triplicate.

Extractable $\mathrm{N}$ (Ext-N) and C (Ext-C) were extracted from $10 \mathrm{~g}$ soil (dry base) with $30 \mathrm{ml}$ of $0.5 \mathrm{M} \mathrm{K}_{2} \mathrm{SO}_{4}$ for $30 \mathrm{~min}$ in an orbital shaker, and the suspension was centrifuged and filtered through filter paper (No. 5C, Advantec, Japan). Ext-N and Ext-C in the extract were determined using a TOC-N auto-analyzer (TOC-V carbon analyzer with IN unit, Shimadzu, Japan). Available P (Avail-P) was measured by Troug-soluble P (Blakemore et al. 1987). Briefly, $0.5 \mathrm{~g}$ soil was extracted with $100 \mathrm{ml} 0.001 \mathrm{M} \mathrm{H}_{2} \mathrm{SO}_{4}$ for $30 \mathrm{~min}$ in an orbital shaker, and passed through a filter (No. 6, Advantec, Japan), and then collected. The soil extract was measured colorimetrically with the molybdate-ascorbic acid method following Kuo (1996), and the absorbance was determined at $880 \mathrm{~nm}$. Soil $\mathrm{pH}$ was measured by the glass electrode method (soil:water ratio 1:2.5).

\section{Sugarcane growth}

Various sugarcane growth parameters were measured at ca. seven months after sugarcane planting (16 ${ }^{\text {th }}$ April 2017), when cane numbers should peak (Allison \& Pammenter 2002). The measurement of growth parameters during the tillering and grand growth phase may help predict sugarcane total biomass at final harvest (Ramesh, 2000). Chlorophyll concentration of the third leaf from the top was measured using a chlorophyll meter (soil plant analysis development SPAD502plus, Konica Minolta, Japan). Cane diameter was measured with an electronic digital caliper. Cane height was measured using a tape measure from the surface of the soil to the tip of the flag leaf. These measurements were conducted for 10 randomly selected plants in each plot. In addition, the numbers of canes were also counted within two rows $\left(14 \mathrm{~m}^{2}\right)$ in each plot. These measured growth parameters are considered to be important values and are related to the final yield of sugarcane (Ramesh \& Mahadevaswamy 2000).

\section{Data analysis}

All the statistical analyses were performed using SYSTAT 12.5 (SYSTAT Software, Richmond, CA, USA).
All data are expressed on a dry-weight basis. To assess the effects of each GM application and sampling time after GM application, we conducted a repeated-measures analysis of variance (RM-ANOVA) for CRO and Cont plots, and for SES and Cont plots, respectively. To evaluate the relationship between the soil enzyme activities and environmental and nutrient factors, we conducted Pearson's correlation analysis. One-way ANOVA was used to analyze each sugarcane growth parameter, and when ANOVA indicated a significant difference, mean comparisons were carried out using post-hoc Tukey multiple comparison tests. In all cases, $P$ $<0.05$ was considered significant.

Based on our field observation and measurement of soil enzymes, nutrients, and other environmental factors, we observed a limited effect of drip irrigation and fertilization on soil enzymes, nutrients, and other environmental factors, because Cont plots were kept bare and there was no unexpected increase in the values throughout the experimental period. In addition, detailed data on the treatment of soil enzymes and nutrients during the GM cultivation period (from May to July) are not presented as little difference was found.

\section{Results}

\section{Seasonal variations in the soil environment}

Figure 1 presents the daily rainfall (RF), SM, AT, and ST fluctuations in the Cont and CRO plots during the one-year experimental period (May 2016 to April 2017). The total rainfall was $1169.1 \mathrm{~mm}$, which is within the average rainfall in this district. The SM content in both plots fluctuated clearly from $15.6 \%$ to $27.5 \%$ during the experimental period. The SM in the Cont plot was relatively high during the GM cultivation period because there was no plant transpiration; there was no clear difference between the CRO and Cont plots after GM application. One month after GM application, there was a substantial rainfall event in early September 2016 (ca. $220 \mathrm{~mm} / 10$ days), followed by little rainfall thereafter. It is exceptional that there was no typhoon in this year, although generally there should be 2-4 typhoons each year. The average AT during the experimental period was $24.5{ }^{\circ} \mathrm{C}$, which fluctuated from $14.5{ }^{\circ} \mathrm{C}$ to $31.1{ }^{\circ} \mathrm{C}$. Average ST in the CRO and Cont plots was $25.0^{\circ} \mathrm{C}$ and $25.5{ }^{\circ} \mathrm{C}$, respectively, and was not clearly different to these after GM application. However, it was clearly higher in the Cont plot $\left(33.3^{\circ} \mathrm{C}\right)$ than in the $\mathrm{CRO}$ plot $\left(29.9^{\circ} \mathrm{C}\right.$ ) during the later $\mathrm{GM}$ growth period (i.e., from June to July), because of the bare soil conditions (no plant cover) in the Cont plot. 


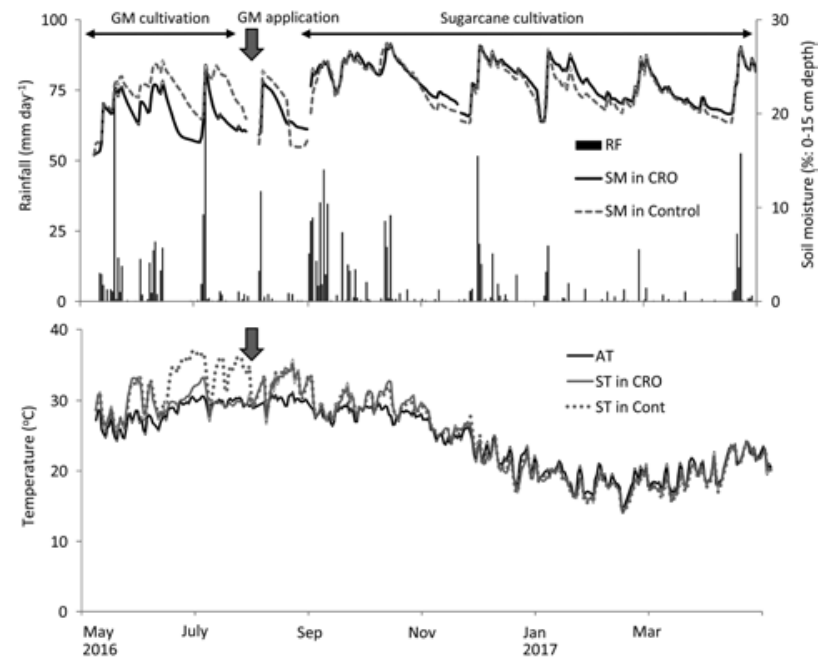

Fig. 1. Fluctuation in (a) daily rainfall and soil moisture contents (SM), and (b) daily averaged air temperature (AT) and soil (5 cm depth) temperature (ST) ) in the Crotalaria juncea (CRO) and control (Cont) plots during the experimental period. The downward arrows indicate the timing of green manure (GM) application.

\section{Seasonal variation in soil enzyme activities and soil nutrients}

Figure 2 shows the seasonal variation in soil enzyme activity (i.e., DH, BG, and PHO) after the application of GM. All enzyme activities significantly fluctuated with time during this period (Table 1), although interactions were detected in some cases. The DH similarly fluctuated in all plots and the average was ca. $0.10 \mu \mathrm{mol} \mathrm{g}^{-1} \mathrm{~h}^{-1}$ across all plots. There was no clear effect of CRO and SES application on DH during this period (Table 1). By contrast, BG in the CRO and SES plots clearly increased after GM application, and these high values were maintained throughout the experimental period. The average BG values in the CRO, SES, and Cont plots were $0.69,0.75$, and $0.59 \mu \mathrm{mol} \mathrm{g}{ }^{-1} \mathrm{~h}^{-1}$, respectively, and there was a clear effect of application of both CRO and SES on $\mathrm{BG}$, although the interaction (CRO $\times$ time) was also detected in the CRO plot (Table 1 ). The PHO gradually increased after the application of GM and tended to decrease after December 2016. The average PHO in the CRO, SES, and Cont plot was 12.2, 11.8, and $10.1 \mu \mathrm{mol}$ $\mathrm{g}^{-1} \mathrm{~h}^{-1}$, respectively, and the effect of both CRO and SES application on PHO was clear, although the interaction was also detected in the SES plot (Table 1).

Figure 3 shows the seasonal variations in soil nutrients (i.e., Ext-C, Ext-N, and Avail-P) after the GM application, although interactions were detected in Ext-N. All nutrients significantly fluctuated with time during this period (Table 1). There was no clear difference in
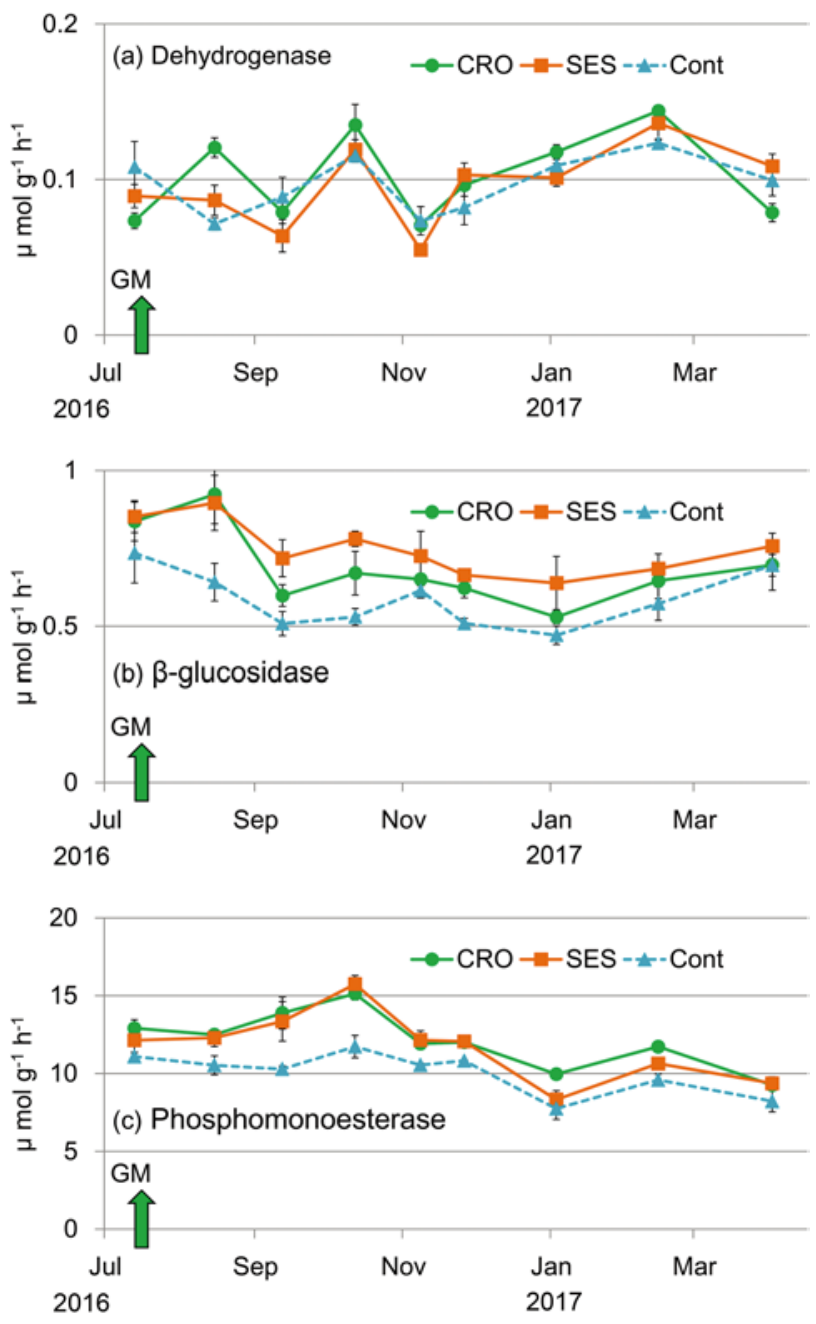

Fig. 2. Fluctuation in (a) dehydrogenase activity, (b) $\beta$-glucosidase activity, and (c) phosphomonoesterase activity in the Crotalaria juncea (CRO), Sesbania cannabina (SES), and control (Cont) plots after GM application in Kitadaito, Okinawa. Error bars indicate the standard error.

Table 1. $F$ values of repeated measures analysis of variance for the effect of each green manure application on soil enzyme activities and nutrients in Kitadaito, Okinawa $(n=9)$.

\begin{tabular}{lccclll}
\hline \hline & DH & BG & PHO & Ext-C & Ext-N & Avail-P \\
\hline CRO & 2.7 & $8.7^{*}$ & $205.2^{* * *}$ & 1.4 & $9.4^{*}$ & 0.1 \\
Time (T) & $16.6^{* * *}$ & $34.4^{* * *}$ & $19.5^{* * *}$ & $4.0^{* * *}$ & $5.0^{* * *}$ & $6.5^{* * *}$ \\
CRO*T & $4.6^{* * *}$ & $11.5^{* * *}$ & 1.5 & 0.6 & $3.8^{* * *}$ & 1.7 \\
SES & 0.1 & $14.6^{*}$ & $11.7^{*}$ & 0.1 & 0.1 & 1.5 \\
T & $15.3^{* * *}$ & $5.9^{* * *}$ & $26.9^{* * *}$ & $4.5^{* *}$ & $5.7^{* * *}$ & $5.8^{* * *}$ \\
SES*T & 2.1 & 1.5 & $2.4^{*}$ & 0.6 & $2.3^{*}$ & 0.4 \\
\hline
\end{tabular}

*: $P<0.05, * *: P<0.01, * * *: P<0.001$

DH: Dehydrogenase, BG: $\beta$-glucosidase,

PHO: Phosphomonoesterase

CRO: Crotalaria, SES: Sesbania 
Ext-C and Avail-P between the treatments through the experimental period, and the average Ext-C in the CRO, SES, and Cont plot was 39.7, 34.9, and $33.2 \mathrm{mg} \mathrm{C} \mathrm{kg}^{-1}$, respectively. The average of Avail-P in the CRO, SES, and Cont plot was 25.3, 21.9, and $24.4 \mathrm{mg} \mathrm{P} \mathrm{kg}$, respectively. By contrast, Ext-N in the CRO and SES plots was temporally increased after GM application, although it soon decreased. The average Ext-N in the CRO, SES, and Cont plots was 12.2, 9.8, and $9.6 \mathrm{mg} \mathrm{N}$ $\mathrm{kg}^{-1}$, respectively, and CRO application significantly increased the Ext-N, although the interaction (CRO $\times$ time) was also detected.

Soil $\mathrm{pH}\left(\mathrm{H}_{2} \mathrm{O}\right)$ slightly fluctuated within 5.0 to 5.5 through the experimental period (data not shown), but there was no clear difference between the treatment plots throughout the experimental period.
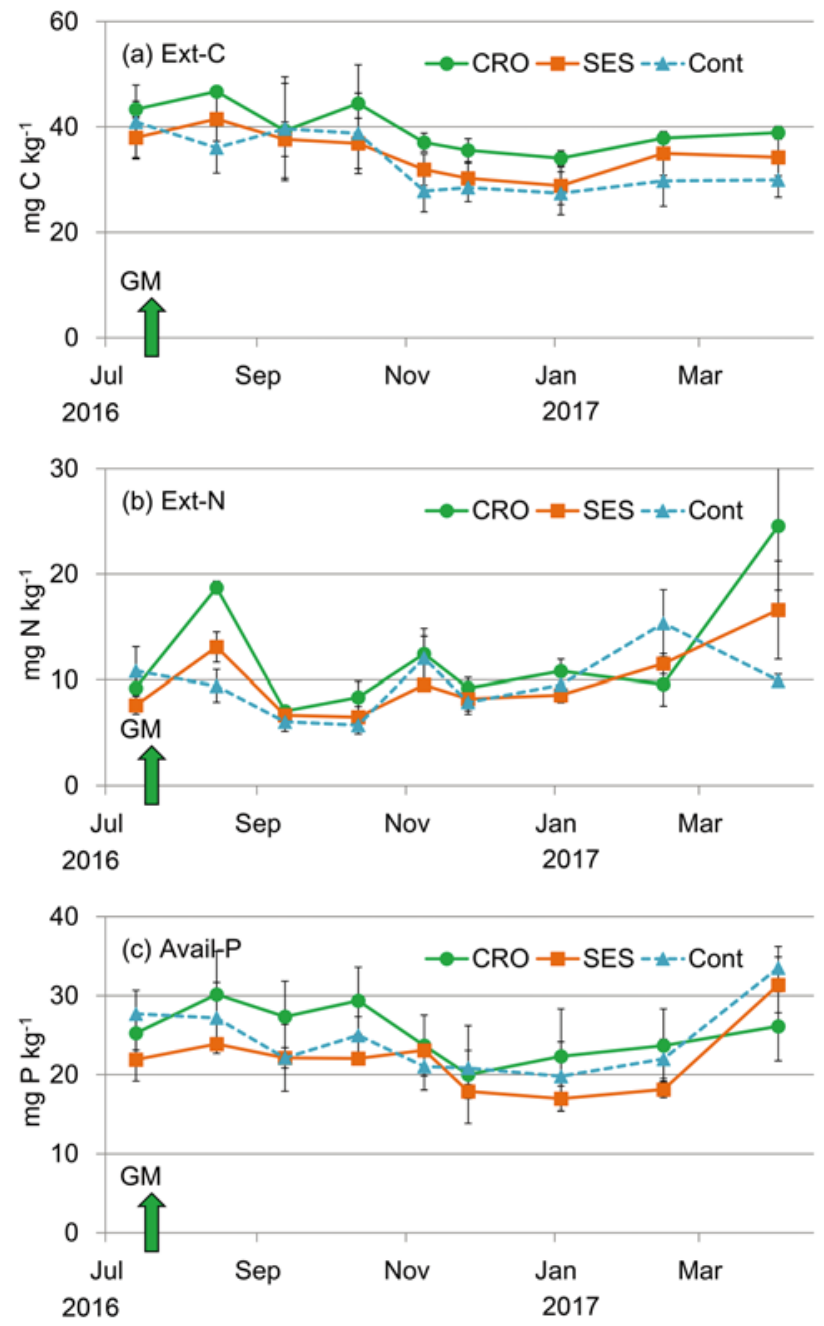

Fig. 3. Fluctuations in (a) extractable carbon (Ext-C), (b) extractable nitrogen (Ext-N), and (c) available phosphorus (Avail-P) in the Crotalaria juncea (CRO), Sesbania cannabina (SES), and control (Cont) plots after GM application in Kitadaito, Okinawa. Error bars indicate the standard error.

\section{Sugarcane growth parameters}

Table 2 presents the sugarcane growth parameters seven months after planting. There was no clear difference between the treatments, except for the number of canes. In both the CRO and SES plots the number of canes significantly increased by $11 \%-20 \%$.

Table 2. Sugarcane growth parameters at 7 months after planting in Kitadaito, Okinawa.

\begin{tabular}{lcccc}
\hline \hline & SPAD & $\begin{array}{c}\text { Cane } \\
\text { diameter } \\
(\mathrm{mm})\end{array}$ & $\begin{array}{c}\text { Height } \\
(\mathrm{m})\end{array}$ & $\begin{array}{c}\text { Number } \\
\text { of cane } \\
\left(14 \mathrm{~m}^{2}\right)\end{array}$ \\
\hline CRO & 39.8 & 29.3 & 1.2 & $39.8 \mathrm{a}$ \\
SES & 38.6 & 29.5 & 1.2 & $37.0 \mathrm{a}$ \\
Control & 41.1 & 28.7 & 1.2 & $33.3 \mathrm{~b}$ \\
\hline
\end{tabular}

CRO: Crotalaria, SES: Sesbania

Different letters indicate significant difference between the treatments, according to Tukey test $(P<0.05)$

\section{Relationship between soil enzyme activities and soil environment or nutrient characteristics}

Table 3 shows the relationship between the soil enzymes and soil environment or nutrient characteristics for all plots for each treatment after GM application. Only AT was significantly negatively correlated with $\mathrm{DH}$ in all plots. The AT and ST were positively correlated with BG significantly, except for AT in the CRO and Cont plots, and ST in the Cont plot. Ext-C was positively correlated with BG in the CRO, SES, and in all other plots, and Avail-P was also positively correlated with BG in the CRO, Cont, and all other plots. The AT and ST were positively correlated with PHO in the SES, Cont, and in all other plots significantly, except for ST in the Cont plot. In addition, Ext-C was positively correlated with PHO in all plots significantly, while Ext-N was negatively correlated with PHO in all plots. SM was not significantly correlated with any soil enzyme activity in this study.

\section{Discussion}

\section{Effect of GM application on soil enzyme activities and soil nutrient dynamics}

We found that both CRO and SES application clearly increased the BG and $\mathrm{PHO}$ activities through the experimental period. BG increased immediately after GM application, indicating the rapid mineralization of applied GM, while PHO increased gradually and peaked at 2-3 months after GM application, indicating that $\mathrm{P}$ mineralization would occur more slowly than $\mathrm{C}$ mineralization. These results indicate that GM application clearly improved both $\mathrm{C}$ and $\mathrm{P}$ cycling by stimulating the microbial activity. Dux et al. (2006) also observed the 
Table 3. Correlation matrix between the soil enzyme activities and environmental and nutrient factors in the Crotalaria juncea (CRO), Sesbania cannabina (SES), Control (Cont), and all treatment plots after GM application in Kitadaito, Okinawa.

\begin{tabular}{|c|c|c|c|c|c|c|c|c|c|c|c|c|}
\hline & \multicolumn{4}{|c|}{$\mathrm{DH}$} & \multicolumn{4}{|c|}{ BG } & \multicolumn{4}{|c|}{ PHO } \\
\hline & $\begin{array}{c}\text { All } \\
(\mathrm{N}=27)\end{array}$ & $\begin{array}{c}\text { CRO } \\
(\mathrm{N}=9)\end{array}$ & $\begin{array}{c}\text { SES } \\
(\mathrm{N}=9)\end{array}$ & $\begin{array}{l}\text { Cont. } \\
(\mathrm{N}=9)\end{array}$ & $\begin{array}{c}\text { All } \\
(\mathrm{N}=27)\end{array}$ & $\begin{array}{l}\text { CRO } \\
(\mathrm{N}=9)\end{array}$ & $\begin{array}{l}\text { SES } \\
(\mathrm{N}=9)\end{array}$ & $\begin{array}{l}\text { Cont. } \\
(\mathrm{N}=9)\end{array}$ & $\begin{array}{c}\text { All } \\
(\mathrm{N}=27)\end{array}$ & $\begin{array}{c}\text { CRO } \\
(\mathrm{N}=9)\end{array}$ & $\begin{array}{l}\text { SES } \\
(\mathrm{N}=9)\end{array}$ & $\begin{array}{l}\text { Cont. } \\
(\mathrm{N}=9)\end{array}$ \\
\hline Air temperature & $-0.41^{*}$ & -0.37 & -0.50 & -0.39 & $0.52^{* *}$ & 0.66 & $0.81^{* *}$ & 0.45 & $0.67 * *$ & 0.66 & $0.72 *$ & $0.72 *$ \\
\hline Soil temperature & -0.37 & -0.27 & -0.49 & -0.38 & $0.54^{* *}$ & $0.71^{*}$ & $0.86^{* *}$ & 0.56 & $0.59 * *$ & 0.62 & $0.69 *$ & 0.63 \\
\hline Soil Moisture & 0.37 & 0.36 & 0.34 & 0.45 & -0.38 & -0.52 & -0.21 & -0.18 & -0.12 & -0.16 & -0.05 & -0.08 \\
\hline Ext-C & 0.11 & 0.16 & -0.08 & 0.11 & $0.54 * *$ & $0.84 * *$ & $0.86^{* *}$ & 0.26 & $0.58 * *$ & 0.57 & 0.52 & 0.57 \\
\hline Ext-N & 0.04 & -0.17 & 0.23 & 0.21 & 0.31 & 0.40 & 0.21 & 0.38 & $-0.42 *$ & -0.63 & -0.55 & -0.46 \\
\hline Avail-P & -0.03 & -0.06 & -0.18 & 0.04 & $0.40 *$ & $0.73^{*}$ & 0.50 & $0.78 *$ & 0.09 & 0.50 & 0.00 & -0.19 \\
\hline
\end{tabular}

*: $P<0.05, * *: P<0.01$

DH: Dehydrogenase, BG: $\beta$-glucosidase, PHO: Phosphomonoesterase

increase of $\beta$-glucosidase activities by GM application, such as Imperatacylindrica and Chromolaenaodorata, in tropical cropland of Cameroon. By contrast, we found little difference in the Ext-C and Avail-Pas a result of GM application. However, in the current study, CRO and SES application should also stimulate the related microbial activity because there was a clear relationship between Ext-C and BG in the CRO, SES, and in all other plots (Table 3). This indicates that Ext-C might also be increased by GM application, although the effect was statistically unclear. This might be because of the heterogeneity (large standard error) of the field experiments and seasonal fluctuations. In the case of Avail-P, because the amount of applied P as GM residues was limited (ca. 10.8-17.7 kg P ha'), it is difficult to evaluate the mineralized P from GM decomposition. Baggie et al. (2004) also discovered a relatively small release of $\mathrm{P}$, owing to the low $\mathrm{P}$ content of plant residue. In addition, the soil on Kitadaito Island is characterized by heavy clay texture and strongly crystallized Fe, causing high $\mathrm{P}$ absorption capacity (Obara et al. 2015). As a result, mineralized P from GM may be immediately absorbed on crystallized Fe ( $\mathrm{Li}$ et al. 1997, Haynes \& Mokolobate 2001), although we did not evaluate the soil microbial biomass $\mathrm{P}$ as an important $\mathrm{P}$ pool in the tropics (Sugihara et al. 2015). On the basis of such little effect of GM application on related soil nutrients (e.g., Ext-C and Avail-P), BG and PHO activities should be more sensitive and should represent a better indicator of soil nutrient flux caused by land management (e.g., GM application) in the sugarcane cropland.

However, unlike BG and PHO, DH showed no clear change following GM application. This is because DH activity is generally considered to be a result of comprehensive metabolic activity of soil microbes
(Dormaar et al. 1984, Tejada et al. 2008), and therefore various environmental and nutrient factors would have a combined effect. On the basis of our correlation analysis, there was little relationship between the $\mathrm{DH}$ and environmental and nutrient factors (only AT for all plots), whereas BG and PHO had a relationship with various factors in each of the plots. This indicates that there was no dominant controlling factor of $\mathrm{DH}$ in this study, perhaps because every tested factor balanced out during the course of the experimental period. Thus, DH activity was considered unsuitable as an indicator of land management under these conditions, although further study is necessary to clarify the controlling factor of DH.

Comparison of the effects of GM application on soil enzymes and nutrients between CRO and SES plots indicated that CRO seemed to have a larger effect on PHO and Ext-N than did SES, while SES seemed to have the larger effect on BG (Table 1). In terms of $\mathrm{N}$ dynamics, Ext-N in the CRO plot clearly increased immediately after application of GM, and was larger than that of SES. In addition, Ext-N in the CRO plot was consistently larger than that in the Cont plot throughout the experimental period, whereas increased Ext-N temporally decreased after one month, possibly owing to the critical leaching following the heavy rainfall event in this period (ca. 220 mm within 10 days). This indicates that CRO could efficiently improve the $\mathrm{N}$ dynamics relative to SES, although the applied $\mathrm{N}$ amount was larger in the SES plot $\left(170 \mathrm{~kg} \mathrm{~N} \mathrm{ha}^{-1}\right)$ than in the CRO plot (130 kg N ha $\left.{ }^{-1}\right)$. At present, it is unclear why CRO performed better than SES for clear $\mathrm{N}$ mineralization, but, based on our observations, the CRO sample was easily ground into a fine powder by the milling operation, while the SES sample was difficult to grind into a clear fine powder because of its woody texture, resulting in the more rapid decomposition and $\mathrm{N}$ 
mineralization of CRO residues than of SES residues. Thomas and Shantaram (1984) found that the application of Mimosa shrub residue (a species of leguminous woody shrub) was decomposed slowly because of the woody nature of its residues compared with the grass legumes in West India. Fosu et al. (2007) also found that CRO had the highest residue quality because of low cellulose, C:N ratio, and lignin: $\mathrm{N}$ ratio. Therefore, differences of plant quality could have strongly affected the decomposition pattern, resulting in different soil enzyme activity and nutrient dynamics in this research, although both GM applications clearly increased the sugarcane numbers, which is one of the most important factors of sugarcane yield (Prammanee et al. 1995, Umrit et al. 2009).

\section{Relationship between soil enzyme activities and soil environmental or nutrient characteristics}

We found a clear relationship between the temperature factor and BG and $\mathrm{PHO}$ activities in this subtropical sugarcane field, and SM was not related to any soil enzyme activities. This indicates that temperature is still an important controlling factor of soil enzyme activities even in the subtropical sugarcane field of Okinawa. This is because there was a clear winter season (AT of $15-20^{\circ} \mathrm{C}$ ), which is likely to have regulated soil enzyme activity (Brzostek \& Finzi 2012, Wallenstein et al. 2012). Steinweg et al. (2012) observed a clear effect of temperature on $\beta$-glucosidase fluctuation in temperate cropland of northern US, although Masto et al. (2006) also observed little effect of temperature on soil enzyme fluctuation in the typical tropical cropland of north India.

We observed a clear relationship between Ext-C and BG in the CRO, SES, and all other plots but not in the Cont plot. This indicates that GM application increased BG through the increment of microbial $C$ substrate, although Ext-C was not significantly increased in the present study. There was no clear fluctuation of BG in the Cont plot, possibly owing to the deficiency of $\mathrm{C}$ substrate (Tejada et al. 2006). Madejon et al. (2007) in their study also observed a clear relationship between the $\beta$-glucosidase, phosphomonoesterase, microbial biomass $\mathrm{C}$, and soil organic $\mathrm{C}$ in a leguminous cropland in Spain. In addition, we also observed the relationship between Avail-P and BG in the CRO, Cont, and all other plots, possibly indicating the insufficiency of $\mathrm{P}$ for soil microbial activity in this strongly weathered soil (Gao et al. 2016). Thus, BG activity was more sensitively related to variations in soil $\mathrm{P}$ conditions than $\mathrm{DH}$ and/or PHO.

\section{Conclusion}

Application of CRO and SES clearly increased the soil enzyme activity (e.g., BG and PHO) during the experimental period in sugarcane cropland of Kitadaito, Okinawa, and finally increased the sugarcane number (increased by ca. 11\%-20\%), but application of CRO and SES did not increase the DH activity and soil nutrients such as Ext-C and Avail-P. Application of CRO also increased the Ext-N; however, SES application did not, which may be because of the different quality and decomposition patterns of the two GMs. Thus, in terms of improvement of soil enzyme and nutrient conditions, CRO would be a better choice of GM species than SES for GM-sugarcane cropping systems in Kitadaito, Okinawa, although further study is necessary for revealing the long-term effects of single or multiple GM application based on the multi-year experiment. In addition, seasonal fluctuations of BG and PHO activities was controlled by temperature even in the subtropical climate condition, and these enzyme activities can be used as an appropriate indicator of land management in terms of soil nutrient flux in the sugarcane cultivation system of Kitadaito, Okinawa.

\section{Acknowledgments}

We thank Mr. E. Taira of Kitadaito Municipal Office for his technical support in the field experiment. We are also deeply indebted to the Editor and two anonymous reviewers for improving our manuscript. Our work was financially supported by grants from the Project of the NARO Bio-oriented Technology Research Advancement Institution (the special scheme project on regional developing strategy).

\section{References}

Allison, J. C. S. and Pammenter, N. W. (2002) Effect of nitrogen supply on the production and distribution of dry matter in sugarcane. South Afr. J. Plant Soil, 19, 12-16.

Baggie, I. et al. (2004) Decomposition and phosphorus release from organic residues as affected by residue quality and added inorganic phosphorus. Agroforestry Syst., 63, 125131.

Bandick, A. K. \& Dick R. P. (1999) Field management effects on soil enzyme activities. Soil Biol. Biochem., 31, 14711479.

Blakemore, L. C. et al. (1987) Methods for chemical analysis of soils. NZ Soil Bureau Scientific Report 80, New Zealand.

Bokhtiar, S. M. \& Sakurai, K. (2005) Effect of application of inorganic and organic fertilizer on growth, yield and quality of sugarcane. Sugar Tech., 7, 33-37.

Brzostek, E. R. \& Finzi, A. C. (2012) Seasonal variation in the temperature sensitivity of proteolytic enzyme activity in temperate forest soils. J. Geophysical Res., 117, 1-10.

Burgos, P. et al. (2002) Changes in soil organic matter, enzymatic activities and heavy metal availability induced 
by application of organic residues. Develop. Soil Sci., 28, 353-362.

Carvalho, N. S. et al. (2015) Short-term effect of different green manure on soil chemical and biological properties. Afr. $J$. Agric. Res., 10, 4076-4081.

Cherr, C. M. et al. (2006) Green manure approaches to crop production: A synthesis. Agronomy J., 98, 302-319.

Debnath, S. et al. (2015) Assessment of microbial biomass and enzyme activities in soil under temperate fruit crops in north western Himalayan region. Soil Sci. Plant Nutr., 15, 848-866.

Dormaar, J. F. et al. (1984) Seasonal changes in carbon content, and dehydrogenase, phosphatase, and urease activities in mixed prairie and fescue grassland Ah horizons. J. Range Management, 37, 31-35.

Dux, J. et al. (2006) Plant leaf residue decomposition, nutrient release and soil enzyme activity. In Prosperity and Poverty in Globalised World-challenges for Agricultural Research, eds. F. M. Asch, et al. University of Bonn, Germany. http:// www.tropentag.de/2006/abstracts/full/351.pdf

Feng, W. et al. (2009) Above- and belowground carbon inputs affect seasonal variations of soil microbial biomass in a subtropical monsoon forest of southwest China. Soil Biol. Biochem., 41, 978-983.

Fosu, M. et al. (2007) Mineralization and microbial biomass dynamics during decomposition of four leguminous residues. J. Biol. Scien., 7, 632-637.

Gao X. et al. (2016) Increase phosphorus availability from the use of alfalfa (Medicago sativa L.) green manure in rice (Oryza sativa L.) agroecosystem. Sci. Rep. 6, 36981, https:// doi.org/10.1038/srep36981.

Gee, G. W. \& Or, D. (2002) Particle-size analysis. In Methods of Soil Analysis, Part 4, Physical Methods, SSSA Book Ser. No. 5, ed. Dane, J. H., Wisconsin, USA, 255-289.

Goyal, S. et al. (1999) Influence of inorganic fertilizers and organic amendments on soil organic matter and soil microbial properties under tropical conditions. Biol. Fertil. Soils, 29, 196-200.

Hayano, K. (1973) A method for determination of $\beta$-glucosidase activity in soil. Soil Sci. Plant Nutr., 19, 103-108.

Hayano, K. (1997) Soil organic matter, soil organism. In Soil Environment Analysis Method, ed. Editorial Committee, Japan, 109-120 [In Japanese].

Haynes, R. J. \& Mokolobate, M. S. (2001) Amelioration of Al toxicity and $\mathrm{P}$ deficiency in acid soils by additions of organic residues: a critical review of the phenomenon and the mechanisms involved. Nutr. Cyc. Agroecosyst., 59, 4763.

Hendershot, W. H. et al. (2008) Ion exchange and exchangeable cations. In Soil Sampling and Methods of Analysis, Second Edition, Canadian Society of Soil Science, ed. Carter, M. R., USA, 197-206.

Kirchner, M. J. et al. (1993) Soil microbial populations and activities in reduced chemical input agroecosystems. Soil Sci. Soc. Am. J., 57, 1289-1295.

Kikuchi, K. et al. (2007) Sugarcane fertilization management in island region of Japan and its impact on production: A case study of Kitadaito Island. Proc. Int. Soc. Sugar Cane Technol., 26, 1842-1847.

Kumar, R. et al. (2013) Green manuring: A boon for sustaninable agriculture and pest management-a review. Agri. Review,
35, 196-206.

Kuo, S. (1996) Phosphorus. In Methods of Soil Analysis, Part 3, Chemical Methods, SSSA Book Ser. No. 5, ed. Sparks D. L., Wisconsin, USA, 869-919.

Li, Y. C. et al. (1997) Transport of phosphorus and fractionation of residual phosphorus in various horizons of a spodosol. Water, Air, Soil Pollut., 109, 303-312.

Mabuza, M. P. et al. (2016) Effects of inorganic fertilizers and Sunhemp (Crotalaria juncea L.) as a green manure crop on Maize (Zea mays L.) growth, seed yield and labour cost. Am. J. Agric. Forestry, 4, 56-63.

Madejon, E. et al. (2007) Soil biochemichal response to longterm conservation tillage under semi-arid Mediterranean conditions. Soil Till. Res., 94, 346-352.

Masto, R. E. et al. (2006) Changes in soil biological and biochemical characteristics in long-term field trial on a sub-tropical inceptisol. Soil Biol. Biochem., 38, 1577-1582.

Matsuoka, M. (2006) Sugarcane cultivation and sugar industry in Japan. Sugar Tech., 8, 3-9.

Miyamaru, N. et al. (2011) Factors limiting organic matter decomposition and nutrient supply of soils on the Daito islands. Soil Microorganisms, 65, 119-124.

Miyamaru, N. (2013) Investigation of microbial properties of soils with improvement of infertile soils in Okinawa. Bull. Okinawa Agric. Res. Cent., 7, 1-44 [In Japanese with English summary].

Obara, H. et al. (2015) Outline of the comprehensive soil classification system of Japan-first approximation. JARQ, 49, 217-226.

Onaga, K. \& Yoshinaga, A. (1988) Physical properties of major Okinawa upland soils. Soil Phys. Cond. Plant Growth Japan, 58, 17-29 [In Japanese with English summary].

Pascual, J. A. et al. (2002) Persistence of immobilized and total urease and phosphatase activities in a soil amended with organic waste. Bioresource Tech., 82, 73-78.

Prammanee, P. et al. (1995) Green manure as a means to sustain sugarcane production in Thailand. Proc. Int. Soc. Sug. Cane Technol., 22, 98-102.

Ramesh, P. (2000) Effect of different levels of drought during the formative phase on growth parameters and its relationship with dry matter accumulation in sugarcane. $J$. Agro. Crop Sci., 185, 83-89.

Ramesh, P. \& Mahadevaswamy, M. (2000) Effect of formative phase drought on different classes of shoots, shoot mortality, cane attributes, yield and quality of four sugarcane cultivars. J. Agro. Crop Sci., 185, 249-258.

Salazar, S. et al. (2011) Correlation among soil enzyme activities under different forest system management practices. Ecol. Engineering, 37, 1123-1131.

Sangakkara, U. R. et al. (2004) Root and Shoot Growth of Maize (Zea mays) as Affected by Incorporation of Crotalaria juncea and Tithoniadiversifolia as Green Manures. J. Agro. Crop Sci., 190, 339-346.

Sangtong, P. \& Katoh, K. (2010) Effects of long-term organic material amendments on soil properties and corn yield in rainfed area of Thailand. JARQ, 44, 133-141.

Sinsabaugh, R. (1994) Enzymic analysis of microbial pattern and process. Biol. Fertil. Soils., 17, 69-74.

Sekiya, K. (1970) Phosphoric acid. In Analysis Methods for Measuring Soil Fertility, ed. Ishizawa, S., Yokendo Co. Ltd, Tokyo, 251-253 [In Japanese]. 
Soil Survey Staff. (2014) Keys to Soil Taxonomy, $12^{\text {th }}$ Edition. U.S. Department of Agriculture, Natural Resources Conservation Service, USA, 173-208.

Steinweg, J. M. et al. (2012) Modeling the effects of temperature and moisture on soil enzyme activity: Linking laboratory assays to continuous field data. Soil Biol. Biochem., 55, 85-92.

Stott, D. E. et al. (2010) Evaluation of $\beta$-glucosidase activity as a soil quality indicator for the soil management assessment framework. Soil Science Society of America Journal, 74, 107-119.

Sugihara, S. et al. (2015) Effects of different phosphorusefficient legumes and soil texture on fractionated rhizosphere soil phosphorus of strongly weathered soils. Biol. Fertil. Soils, 52, 367-376.

Surucu, A. et al. (2014) Effects of green manuring on soil enzyme activity. Fresenius Environ. Bull., 23, 2126-2132.

Tabatabai, M. A. (1982) Soil enzymes. In Methods of Soil Analysis Part 2 Chemical and Microbiological Properties. Agronomy No. 9 ASA and SSSA, eds. Page, A. L. et al. Madison, USA, 903-948.

Tabatabai, M. A. (1994) Soil enzymes. In Methods of Soil Analysis Part 2 Chemical and Microbiological Properties. SSSABook Series:5, eds. Weaver, R. W. et al. American Society of Agronomy, Madison, USA, 775-833.

Tejada, M. et al. (2006) Application of two organic amendments on soil restoration: Effects on the soil biological properties.
J. Environ. Qual., 35, 1010-1017.

Tejada, M., et al. (2008) Application of a green manure and green manure composted with beet vinase on soil restoration: effects on soil properties. Bioresource Tech., 99, 4949-4957.

Thomas, G. V. \& Shantaram, M. V. (1984) In situ cultivation and incorporation of green manure legumes in coconut basins. An approach to improve soil fertility and microbial activity. Plant Soil, 80, 373-380.

Tokashiki, Y. (1993) The characteristic properties of the Shimajirimahji and Jahgaru soil in Okinawa Prefecture. Pedologist, 37, 99-112 [In Japanese].

Umrit, G. et al. (2009) Nitrogen benefits of legume green manuring in sugarcane farming systems in Mauritius. Sugar Tech., 11, 12-16.

Wallenstein, M. D. et al. (2012) A litter-slurry technique elucidates the key role of enzyme production and microbial dynamics in temperature sensitivity of organic matter decomposition. Soil Biol. Biochem., 47, 18-26.

Yoshida, K. et al. (2016) Low nitrogen availability and shallow plow layer decrease sugarcane (Saccharum officinarum L.) productivity in Kitadaito Island, Japan. Soil Sci. Plant Nutr., 62, 504-510.

Zhao, D. et al. (2013) Sugarcane leaf photosynthesis and growth characters during development of water-deficit stress. Crop Sci., 53, 1066-1075. 